\title{
The effect of improperly contoured and poor fitting restorations to patient with oral lichen planus: periodontal and prosthetic treatment
}

\author{
Jin-Beom Shin, Jin-Hyun Cho, Cheong-Hee Lee* \\ Department of Prosthodontics, School of Dentistry, Kyungpook National University, Daegu, Republic of Korea
}

Oral lichen planus (OLP) is a common mucocutaneous disease, which presents as bilateral or multiple lesions. The several factors are implicated in etiology of OLP such as dental restorations, systemic disease, drugs and stress. Especially the influence of dental restorations and plaque control for OLP has been the interest in dentistry. This case is about OLP patient having poor contoured and ill-fitting metal ceramic restorations. The patient in this study has suffered from OLP for a long time, particularly after restoration of metal ceramic restorations on both posterior teeth of maxilla and mandible. This study reported that OLP lesion recovered effectively by improving the contour and fitness of restorations with plaque control. (J Dent Rehabil Appl Sci 2015;31(4):371-7)

Key words: oral lichen planus; dental restorations; oral hygiene

\section{서론}

편평태선은 피부, 점막 또는 양측에 다발성의 병소가 만성으로 나타나는 것이 특징인 흔한 질환이다. 이는 표 층부 상피와 결체조직 사이의 접촉면에서 면역매개변 성에 의해 야기되는 질환이다. ${ }^{1,2}$ 구강 내 병소는 다양하 여 기본적으로 여섯 개의 부류로 나눌 수 있다. 망상형 (reticular), 구진형(popule)과 용균반형(plaque)은 표층부 비후로 백색 병소로 나타나고 위축형(atrophic), 미란형 (erosive), 수포형(bullous)은 임상적으로 흔히 궤양으로 나타난다. ${ }^{3}$ 그 중에서 망상형의 형태가 상대적으로 자발 적인 치유를 보이면서 좋은 예후를 나타내는 반면, 미란 형이 심한 통증과 함께 빈번하게 악화되고 오랫동안 지 속된다. ${ }^{4}$ 주로 30 대 이상의 여성에서 호발하며 스트레스, 전신질환, 구강 내 수복물 및 구강 위생 등의 여러 원인 에 의해 발생한다고 알려져 있으며 이에 대해서 많은 연 구와 논쟁이 이루어지고 있다. ${ }^{1}$

*Correspondence to: Cheong-Hee Lee

Professor, Department of Prosthodontics, Kyungpook University Dental Hospital 2175 Dalgubeol-daero, Jung-gu, Daegu, 41940, Republic of Korea

Tel: +82-53-600-7673, Fax: +82-53-427-0778, E-mail: chlee@knu.ac.kr

Received: August 3, 2015/Last Revision: October 16, 2015/Accepted: December 5, 2015
편평태선을 유발하는 여러 가지 요인 중에서 치과 영 역과 관련된 것으로는 첫 번째로 치과용 수복물을 들 수 있다. 예전부터 치과 수복물과 알레르기 반응 사이의 연 관성에 대해 많은 연구가 있었으며 이런 연구들의 대부 분은 치과용 금속 재료와 구강 점막의 알레르기 반응에 대한 것이었다. ${ }^{5,6}$ 치과용 주조 합금이 구강 내 환경에 노 출되게 되면 분해 반응이 일어나는데 이는 대부분 침이 만들어내는 구강 환경에 의한 것이며 개개인 혹은 시간 에 걸쳐서 다르게 나타날 수 있다. ${ }^{7}$ 이런 분해 반응을 통 해 유리된 요소는 부정적인 반응을 일으켜 알레르기 반 응이나 편평태선 혹은 치은염을 유발하는 원인이 된다. ${ }^{8}$ 주조 합금의 성분 중에서 가장 많이 보고된 것은 니켈이 다. 이는 고정성 수복물이나 교정용 장치에 흔히 사용되 는 금속에 포함된 성분이기 때문에 치과 영역에서 특별 한 관심을 보이고 있다. ${ }^{9}$

편평태선과 바이러스 사이의 연관성에 대해서도 논쟁 이 이루어지고 있다. 그 중 Hepatitis C virus (HCV)의 감

Copyright $@ 2015$ The Korean Academy of Stomatognathic Function and Occlusion. (c) It is identical to Creative Commons Non-Commercial License. 
염과 편평태선과의 연관 관계는 1991년 Mokni 등에 의 해 처음 보고되었고 그 이후로도 많은 연구가 발표되었 지만 병인론에 대해서는 여전히 불명확하다. ${ }^{10}$ 여러 가 설 중에 하나는 $\mathrm{HCV}$ 가 구강 점막에 자신을 복제하여 특별한 T세포를 끌어들임으로써 자가 면역 반응을 일으 킬 수 있다는 것이다. ${ }^{11}$ Pilli 등은 ${ }^{12}$ 편평태선 환자의 구 강 내 병소와 말초혈관을 조직 검사하여 구강 내 병소에 $\mathrm{HCV}$ 에 특화된 $\mathrm{CD} 4+$ 와 $\mathrm{CD} 8+\mathrm{T}$ 세포가 말초혈관보다 더 쉽게 발견된다고 실험적으로 이를 증명하였다. 아직 명확한 병인론을 밝히진 못했지만 편평태선과 HCV와 의 연관관계가 있는 것은 확실하다.

다음은 구강 위생과 관련된 것이다. 구강 위생이 불량 하다고 해서 편평태선을 직접적으로 유발하는 것은 아 니지만 철저한 위생 관리와 치주 치료를 받은 환자에게 서 편평태선이 호전되었다고 보고된 바 있다. ${ }^{13,14}$ 구강 내 기계적 자극이나 내독소와 같은 외부적 요인과 유사 하게 치태의 침착은 상피 조직에 인터루킨 I의 분비를 가져온다. ${ }^{15}$ 인터루킨 I은 림프구와 대식세포의 활성과 관련 있는데 이를 통해 이미 존재하고 있는 편평태선과 같은 치주 병소의 악화를 가져올 수 있다. ${ }^{13}$

본 증례에서는 수년 전 편평태선이 발생하여 약물 치 료를 받아왔으나 호전 없이 증상의 악화와 약화를 반복
해 온 환자에 대한 것으로, 하악 좌우측 구치부가 불량 한 변연 적합도와 부적절하게 형성된 외형을 가진 금속 보철물로 수복되어 있었다. 이 환자의 병소의 경우 금속 알레르기에 의한 반응 혹은 보철물에 의한 협점막 자극 및 구강 위생 불량에 의한 반응으로 나타났을 가능성이 있다. 이에 환자의 금속 보철물을 제거하여 임시수복물 로 대체한 뒤 병소가 치유되는 양상을 관찰하고 보철물 경계부의 부적합과 과풍융이 편평태선의 한 기여요인이 될 수 있음을 보여주는 좋은 증례이기에 보고하고자 한 다.

\section{증례 보고}

본 환자는 58세 남자로 구치 교합이 잘 맞지 않고 저 작 시 통증을 호소하며 의치 제작을 주소로 본원에 내원 하였다. 좌우 협측 점막에 구강 내과에서 편평태선으로 진단 받은 병소가 존재하였고, 상악 좌우에 금속도재관 으로 수복된 제1, 2대구치가 모두 심한 우식과 치주질환 에 이환되어 있었다(Fig. 1).

환자는 약 10 년 전에 C형 간염으로 진단 받고 현재까 지 증상 관찰 중에 있으며 그 비슷한 시기에 편평태선 이 나타났다고 했다. 그리고 좌우측의 구치부에 금속도
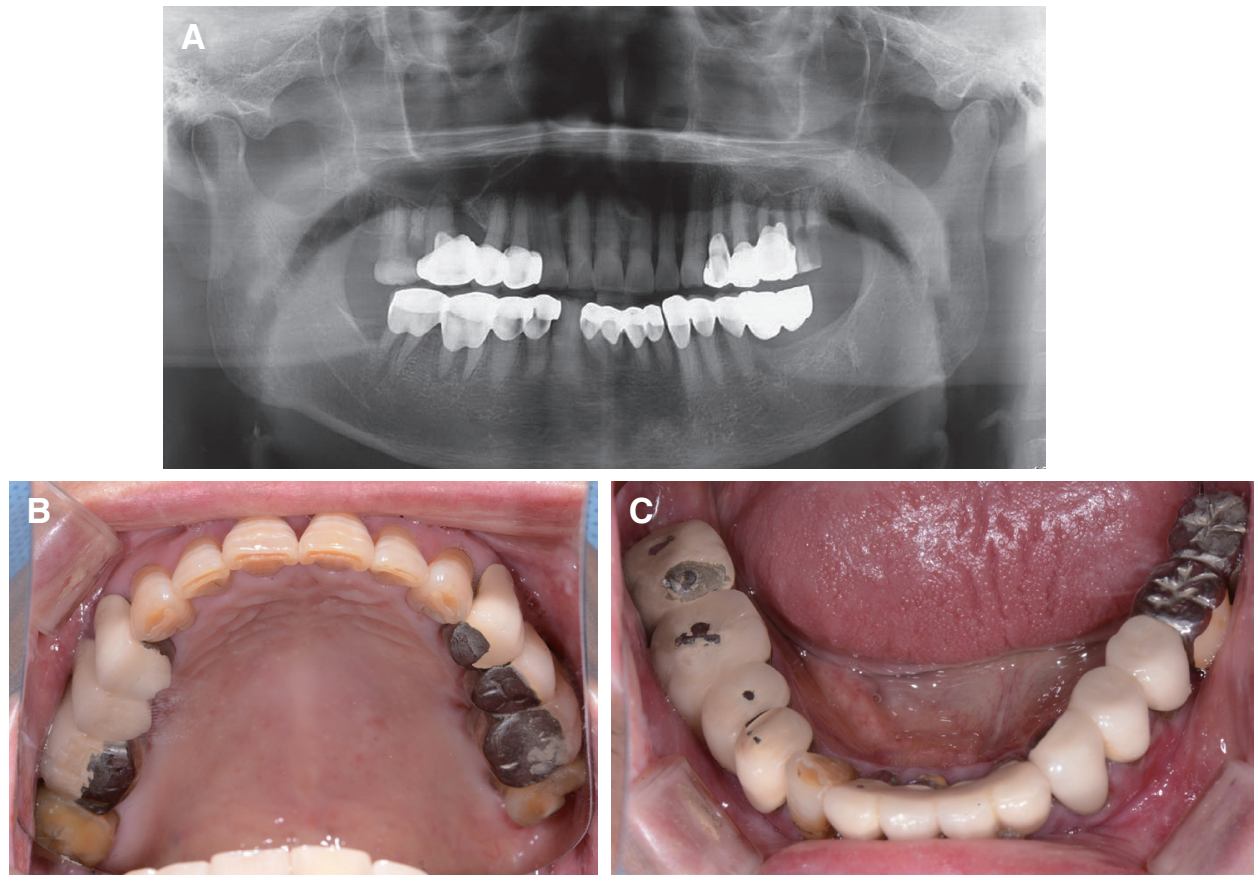

Fig. 1. Large and bulky appearance on right posterior prosthodontic restoration of mandible. (A) Panoramic radiographic image, $(B, C)$ intraoral photo images. 
재관으로 수복한 이후에 편평태선의 증상이 더 심해졌 다고 초진 시 언급했다. 수복된 금속도재관의 형태는 정 상적인 형태보다 크게 제작되어 있었고 외형도 자연스 럽지 못하게 형성되어 있었다. 양측 하악 구치부쪽 협측 전정은 매우 얕고 좁아서 정상적인 형태보다 크게 제작 된 금속도재관에 의해 협측 점막에 기계적인 자극이 가 해지고 구강 위생 관리도 잘 이루어지지 못하는 상태였 다(Fig. 2).

초진 당시 기존에 수복되어 있던 금속도재관을 제거 하고 지대치 재평가 및 임시치아 제작을 계획했다. 우 측 보철물부터 제거 시행하였다. 보철물이 제거된 치아
는 치석과 치태로 심하게 오염되어 있는 상태였고 협측 점막은 망상형과 미란형의 편평태선이 관찰되었다(Fig. 3). 예후가 불량할 것으로 판단되는 \#46, 47 치아를 발 거하고 남은 지대치에 임시치아를 제작했다. 다음 일주 일 후 좌측 구치부의 \#44-47 고정성 금속도재관 보철물 을 제거했다. 우측에 비해 지대치와 점막의 상태가 양호 한 편이었다. 보철물 제거 및 발치를 시행한 하악 우측 의 협측 점막은 미란형의 편평태선이 용균반을 형성하 고 있는 것을 관찰할 수 있었다(Fig. 4). 좌측 지대치도 우측과 동일하게 임시치아를 제작하고 증상 관찰하기로 했다.
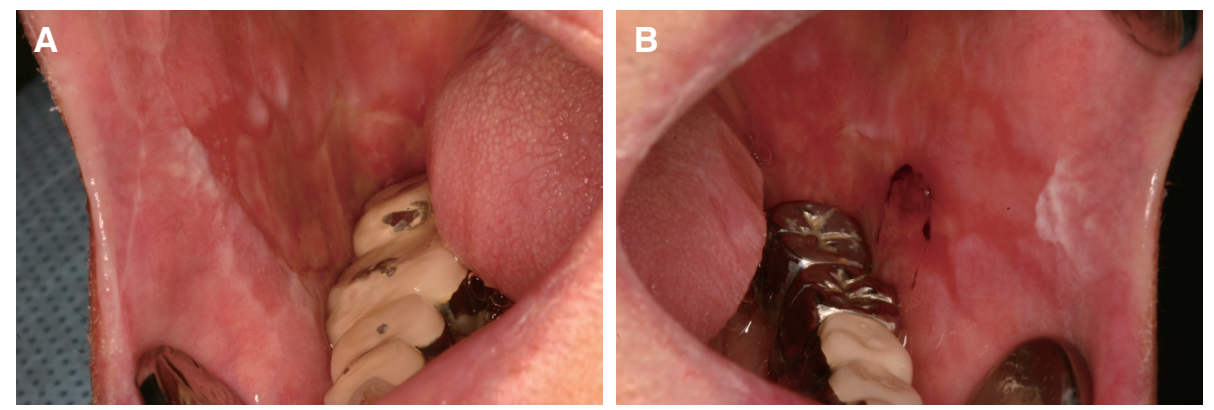

Fig. 2. Reticular type of OLP on both buccal mucosa. (A) Right side, (B) Left side.
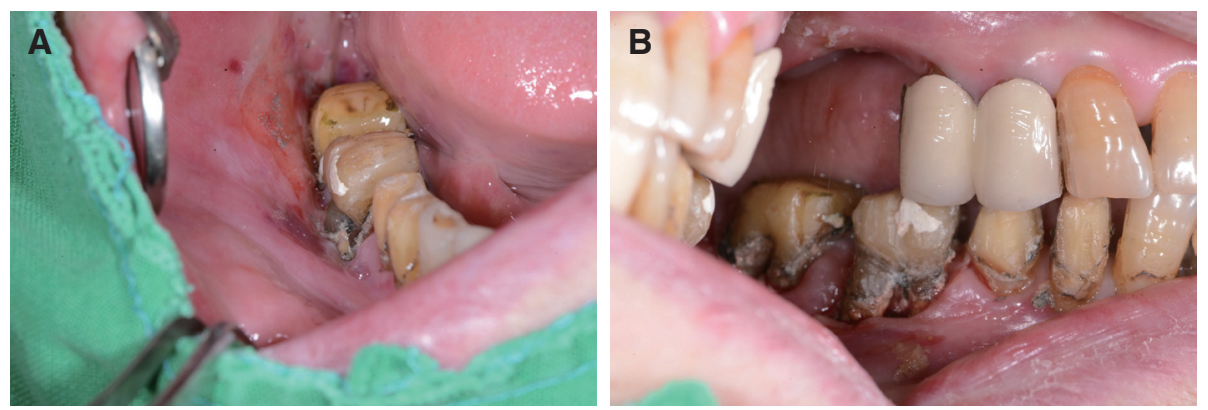

Fig. 3. Note erosive type of OLP (A) and severe deposition of calculi on right molar teeth of mandible (B).

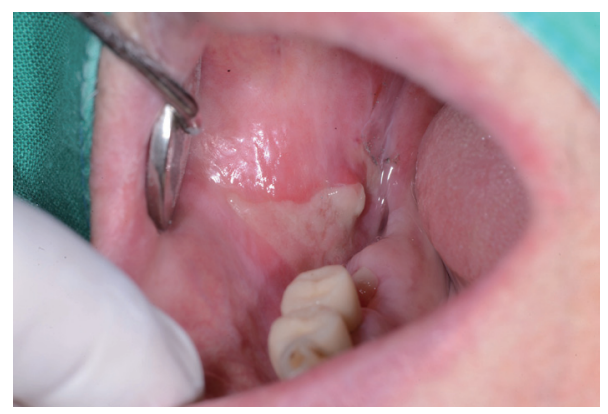

Fig. 4. Transition to plaque type of right OLP lesion after removal of prosthetic restoration. 
임시치아를 제작하고 전반적인 치주치료를 병행하고 한 달 후에 재 내원하였다. 우측의 용균반은 지난 내원 시 보다 절반 이상 많이 줄어든 상태였으나 좌우측의 편 평태선 증상의 큰 호전은 없었다.

3 개월 후에 내원했을 때는 좌우측의 협측 점막의 병소 가 거의 사라지고 환자의 주관적인 통증도 많이 줄어들 었다(Fig. 5). 증세가 호전됨에 따라 임시 수복물을 최종 수복물로 교체하는 것을 계획했다. 최종 수복물은 기존 에 수복되어 있던 금속도재관과 동일한 재질로 제작하기 로 하였다. 금속도재관으로 교체한 후 증상의 변화가 나 타나면 최종 수복물의 재질의 변경을 고려하기로 했다.

통상적인 방법에 의해 인상채득 후 금속도재관 제작 하였다. 기존의 보철물 제거 후 약 6 개월에 최종 보철물 완성 후 임시 접착 시행한 후 좌우측 협측 점막의 변화 를 관찰했다. 한 달 가량 증상 관찰한 결과 증상의 악화 보이지 않아 최종 접착을 시행했다(Fig. 6).

최종 접착을 시행한 5 개월 후 내원에서도 증상의 변화 는 없었으며 환자의 주관적인 통증이나 불편감도 많이 감소한 상태였지만 신체 상태에 따라 통증이나 불편감 이 나타났다고 호소했다.

\section{고찰}

편평태선은 원인불명의 중층편평상피의 염증성 병변 으로 $0.2 \%$ 에서 $2.3 \%$ 정도의 유병율을 보이고 있으며 치과의사가 흔히 만날 수 있는 모든 질병 중에 약 $0.6 \%$ 에 이른다. ${ }^{16}$ 편평태선에 대한 여러 연구가 진행되었지 만 아직 병인론이 명확하게 밝혀지지 않았다. 최근 연구 에서는 면역학적 반응이 편평태선 발생에 중요한 역할 을 한다고 제시했다. ${ }^{17}$ 이와 같은 주장은 편평태선이 자 가세포독성을 가진 $\mathrm{CD} 8+\mathrm{T}$ 세포가 구강 내 상피세로의 세포사멸을 일으키기 때문이라고 설명한다. $\mathrm{T}$ 세포의 활 성화와 관련된 항원들은 내인적 항원과 외인적 항원으 로 나뉘며 약, 구강 내 수복물, 만성간질환, 스트레스 등 여러 가지가 있다. 이처럼 여러 가지 항원에 의한 병인 론이 제기되고 있고, 각 병인론에 대한 논쟁이 계속 이 어지고 있는 중이다.

편평태선을 가지고 있는 본 증례의 환자는 $\mathrm{C}$ 형 간염 이라는 전신질환을 가지고 있었고, 부적절하게 형성된 금속도재관이 좌우측 구치부에 수복되어 있었다. 이 환 자의 병변은 현재까지 제시되고 있는 여러 가지 편평태
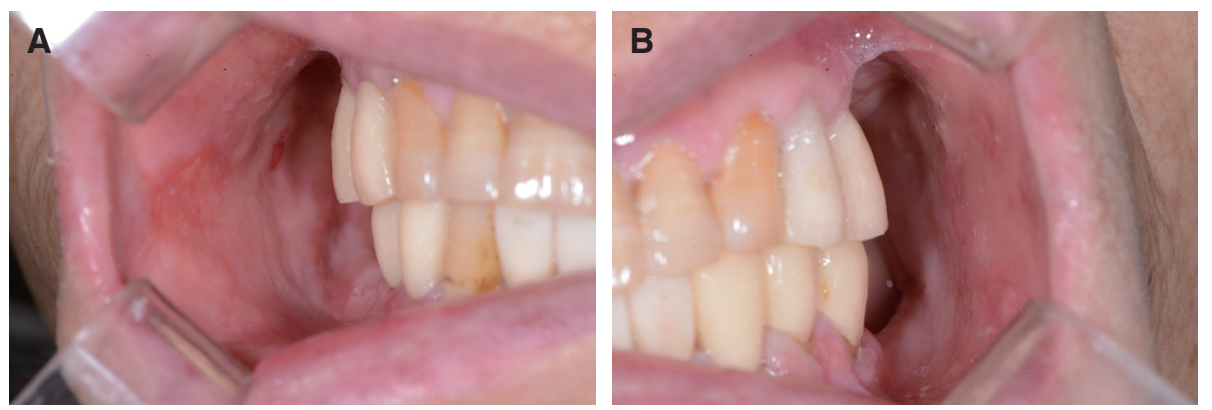

Fig. 5. After 3 month, improvement of lesions on both side. (A) Right side, (B) Left side.
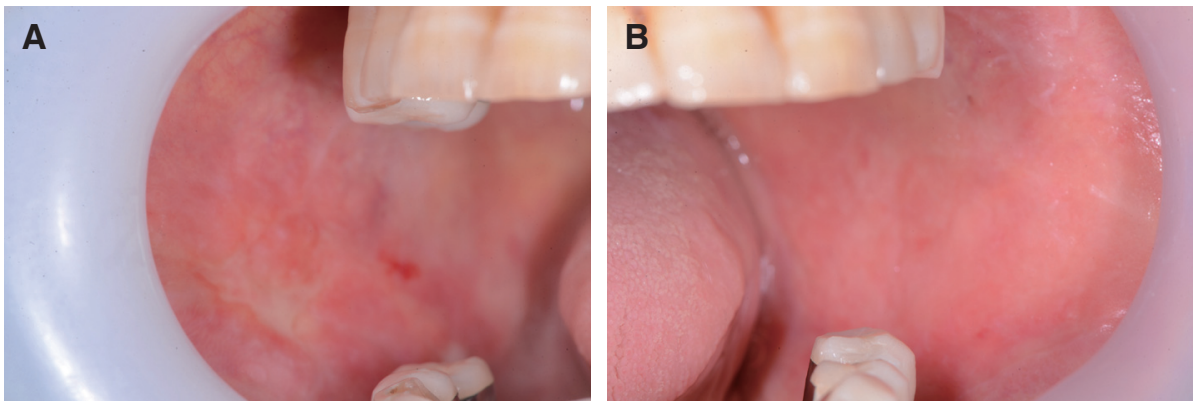

Fig. 6. After 6 month, maintenance of both buccal mucosa. (A) Right side, (B) left side. 
선의 원인들 중에 세 가지 요인들에 의해 복합적으로 나 타났다고 볼 수 있다. 그 첫 번째가 C형 간염 바이러스에 의한 것이다. 많은 연구들이 편평태선과 바이러스와의 연관성에 대해 보고한 바 있으며 특히 가장 폭넓게 연구 된 것은 인유두종 바이러스(human papilloma virus)와 C형 간염 바이러스에 관한 것이다. C형 간염 바이러스 에 의한 편평태선 발생의 기전에 대해서는 정확히 알려 진 것은 없고 $\mathrm{C}$ 형 바이러스가 자가면역에 관련되어 편 평태선을 일으키거나 직접적으로 세포 복제에 관여하 여 면역학적 변화를 가져오기 때문이라고 추측하고 있 다. ${ }^{18,19}$ 하지만 편평태선을 가진 환자에서 다른 일반 사 람들에게서 보다 높은 비율로 만성 간염이 발견되고 B 형 간염 예방 접종 후에 편평태선과 같은 질환이 나타났 다는 보고들은 간염 바이러스가 편평태선에 연관성이 있다는 것을 지지한다고 할 수 있다. ${ }^{19,20}$

다음은 부적절하게 형성된 금속도재관의 수복에 의해 받은 영향에 대해 생각해보고자 한다. 환자의 좁고 얕은 전정과 함께 외형이 크게 제작된 금속도재관에 의해 협 측 점막은 쉽게 자극을 받았고 구강 위생 관리도 적절히 이루어지지 않아 수복된 치아 주위로 치태와 치석의 침 착이 많았다. 치태와 치석과 같은 구강 위생에 관한 문 제와 점막에 대한 자극은 편평태선을 직접적으로 일으 키는 것에는 논란의 여지가 있지만 이미 발생되어 있는 편평태선의 증상을 악화시킨다는 연구는 많이 발표되 었다. Heinz는 ${ }^{14}$ 1985년 치주치료를 통한 치태의 제거 와 감소는 점막과 치은 병소에서의 호전을 관찰하고 보 고하였다. 또 다른 연구에서도 11명의 환자를 철저한 구 강 위생 관리를 통해 편평태선과 관련된 병소와 증상의 호전을 나타낸 것을 보고한 바 있다. ${ }^{13}$ 본 증례의 환자에 게서도 불량한 보철물 대신 변연 적합도를 높이고 치아 외형과 거의 유사하게 제작한 보철물과 전반적인 치근 활택술을 통한 구강 위생 관리 후의 변화는 앞서 발표된 연구들의 결과를 뒷받침한다고 할 수 있다.

협측 점막으로의 자극과 구강 위생 문제 말고도 금속 도재관 자체의 성분에 의한 원인도 의심할 수 있다. 구 강 내 수복물에 의한 편평태선의 발생은 여러 저자들에 의해 주장되어 왔는데 특히 아말감 수복물이나 니켈을 포함하고 있는 금속수복물의 영향에 대한 연구가 많이 발표되었다. 치과용 수복물에 의한 부작용은 만성적인 자극에 의한 구강 내 징후로 나타나거나 림프구와 연관 된 지연성 과민반응으로 나타날 수 있다. 지연성 과민반 응의 경우 구강 내 수복물이 오랜 시간이 지나면서 어떤
성분이 수복물로부터 유리되게 되는데 이 유리된 성분 이 점막의 기저층에 있는 각질세포의 항원성을 변화시 킬 수 있다. 이러한 각질세포의 변화는 대식세포와 $\mathrm{T}$ 세 포와 연관된 면역반응을 일으켜 자가면역성 질환을 나 타낼 수 있다. 알레르기성 반응도 지연성 과민반응의 하 나로 니켈과 코발트가 대표적인 항원으로 보고된 바 있 다. 반면 만성적인 자극은 림프구에 의해 유도된 반응이 아니라 화학물질의 직접적인 접촉에 의해 유도되는 국 소적 염증 반응의 형태이다. 따라서 구강 점막에 독성 물질의 반복적인 혹은 지속적인 접촉 부위에 국한되어 나타나고, 아말감에 의한 점막의 독성 반응이 대표적이 라고 할 수 있다. ${ }^{8,17}$

본 증례에서는 보철물 제거와 구강 위생 관리 후에도 편평태선의 완치는 보이지 않았다. 따라서 $\mathrm{C}$ 형 간염 바 이러스에 대한 환자의 전신질환 관리가 더 필요할 것으 로 보인다. 또한 환자에게 다시 금속도재관을 제작하여 수복한 뒤의 추적관찰에서는 증상의 변화가 악화 없이 비슷한 증상을 지속적으로 보이는 것으로 볼 때 환자의 편평태선이 금속에 대한 알레르기 반응은 아니라고 볼 수 있다. 하지만 구강 내 분해 반응으로 인한 증상이 다 시 나타날 수도 있으므로 앞으로 지속적인 관리 및 추적 관찰이 필요할 것이다.

\section{결론}

구강 내 불량한 적합이나 외형의 과풍융과 같은 부적 절한 형태의 보철물이 편평태선의 증상 악화를 가져올 수 있으며, 이와 같은 보철물의 개선과 철저한 치태관리 를 통한 구강위생의 향상이 편평태선의 증상을 완화시 킬 수 있었다.

\section{References}

1. Sugerman PB, Savage NW, Walsh LJ, Zhao ZZ, Zhou XJ, Khan A, Seymour GJ, Bigby M. The pathogenesis of oral lichen planus. Crit Rev Oral Bio Med 2002;13:350-65.

2. Farhi D, Dupin N. Pathophysiology, etiologic factors, and clinical management of oral lichen planus, part I: facts and controversies. Clin Dermatol 2010;28:100-8.

3. Andreasen JO. Oral lichen planus. 1. A clinical evaluation of 115 cases. Oral Surg Oral Med Oral 
Pathol 1968;25:31-42.

4. Mollaoglu N. Oral lichen planus: a review. Br J Oral Maxillofac Surg 2000;38:370-7.

5. Lyzak WA, Flaitz CM, McGuckin RS, Eichmiller F, Brown RS. Diagnosis and treatment of an oral base-metal contact lesion following negative dermatologic patch tests. Ann Allergy 1994;73:161-5.

6. Mizoguchi S, Setoyama M, Kanzaki T. Linear lichen planus in the region of the mandibular nerve caused by an allergy to palladium in dental metals. Dermatology 1998;196:268-70.

7. Wataha JC, Malcolm CT, Hanks CT. Correlation between cytotoxicity and the elements released by dental casting alloys. Int J Prosthodont 1995;8:9-14.

8. Issa Y, Duxbury AJ, Macfarlane TV, Brunton PA. Oral lichenoid lesions related to dental restorative materials. Br Dent J 2005;198:361-6.

9. Morris HF. Veterans Administration Cooperative Studies Project No. 147. A precementation comparison of metal ceramic restorations made with a gold-containing alloy or alternative alloys. J Prosthet Dent 1991;65:196-205.

10. Mokni M, Rybojad M, Puppin D Jr, Catala S, Venezia F, Djian R, Morel P. Lichen planus and hepatitis C virus. J Am Acad Dermatol 1991;24:792.

11. Carrozzo M, Scally K. Oral manifestations of hepatitis C virus infection. World J Gastroenterol 2014 28;20:7534-43.

12. Pilli M, Penna A, Zerbini A, Vescovi P, Manfredi M, Negro F, Carrozzo M, Mori C, Giuberti T, Ferrari C, Missale G. Oral lichen planus pathogenesis: A role for the HCV-specific cellular immune response. Hepatology 2002;36:1446-52.

13. Holmstrup P, Schiøtz AW, Westergaard J. Effect of dental plaque control on gingival lichen planus. Oral Surg Oral Med Oral Pathol 1990;69:585-90.

14. Erpenstein H. Periodontal and prosthetic treatment in patients with oral lichen planus. J Clin Periodontol 1985;12:104-12.

15. Katz J, Goultschin J, Benoliel R, Rotstein I, Pisanty S. Lichen planus evoked by periodontal surgery. J Clin Periodontol 1988;15:263-5.

16. Scully C, Carozzo M. Oral mucosa disease: lichen planus. Br J Oral Maxilofac Surg 2008;46:15-21.

17. Ismail SB, Kumar SK, Zain RB. Oral lichen planus and lichenoid reactions: etiopathogenesis, diagnosis, management and malignant transformation. J Oral Sci 2007;49:89-106.

18. Ibrahim HA, Baddour MM, Morsi MG, Abdelkader AA. Should we routinely check for hepatitis B and $\mathrm{C}$ in patients with lichen planus or cutaneous vasculitis? East Mediterr Health J 1999;5:71-8.

19. Ko HM, Hernandez-Prera JC, Zhu H, Dikman SH, Sidhu HK, Ward SC, Thung SN. Morphologic features of extrahepatic manifestations of hepatitis C virus infection. Clin Dev Immunol 2012;2012: 740138.

20. Gheorghe C, Mihai L, Parlatescu I, Tovaru S. Association of oral lichen planus with chronic $\mathrm{C}$ hepatitis. Review of the data in literature. Maedica (Buchar) 2014;9:98-103. 


\section{구강 내 불량한 보철물 수복이 편평태선에 미치는 영향에 대한 치주, 보철적 접근}

\section{신진범, 조진현, 이청희*}

경북대학교 치의학전문대학원 치과보철학교실

편평태선은 피부, 점막에 양측성 또는 다발성의 병소가 만성으로 나타나는 흔한 질환이다. 편평태선을 발생시키는 원 인으로는 구강 내 수복물, 전신질환, 약물, 스트레스 등 여러 가지 요인이 작용한다고 알려져 있다. 그 중 편평태선에 대 한 구강 내 수복물과 위생관리의 영향은 치과 영역에서 큰 관심이 되어왔다. 본 증례는 형태가 불량하고 경계가 잘 맞 지 않는 보철물이 수복되어 있는 편평태선 환자에 관한 것이다. 환자는 오랜 시간 동안 편평태선으로 치료받고 있었고 양측 구치부에 금속도재관을 수복한 이후 증상이 더욱 악화되어 있었다. 불량한 적합도와 외형을 보이는 금속도재관을 제거하고 치주치료를 동반하여 보철물의 형태와 변연 적합도를 개선시킴으로써 편평태선이 효과적으로 줄어들었기에 다음을 보고자 한다.

(구강회복응용과학지 2015;31 (4):371-7)

주요어: 편평태선; 보철물; 수복물; 구강위생 